\title{
An IGF-I promoter polymorphism modifies the relationships between birth weight and risk factors for cardiovascular disease and diabetes at age 36
}

\author{
Saskia J te Velde* ${ }^{* 1}$, Elisabeth FC van Rossum ${ }^{\dagger 2}$, Paul G Voorhoeve ${ }^{\dagger 3}$, \\ Jos WR Twisk ${ }^{1,4}$, Henriette A Delemarre van de Waal ${ }^{3}$, Coen DA Stehouwer ${ }^{5}$, \\ Willem van Mechelen ${ }^{1,6}$, Steven WJ Lamberts ${ }^{2}$ and Han CG Kemper ${ }^{1}$
}

\begin{abstract}
Address: ${ }^{1}$ Institute for research in extramural medicine (EMGO), VU University Medical Center, Amsterdam, The Netherlands, ${ }^{2}$ Department of Internal Medicine, Erasmus MC, Rotterdam, The Netherlands, ${ }^{3}$ Department of Pediatric Endocrinology, VU University Medical Center, Amsterdam, The Netherlands, ${ }^{4}$ Department of Clinical Epidemiology and Biostatistics, VU University Medical Center, Amsterdam, The Netherlands, ${ }^{5}$ Institute for Cardiovascular Research and Department of Internal Medicine, VU University Medical Center, Amsterdam, and Department of Medicine, University Hospital Maastricht, Maastricht, The Netherlands and 'Department of Social Medicine and Body@Work research centre for physical activity, work and health TNO-VU, VU University Medical Center, Amsterdam, The Netherlands

Email: Saskia J te Velde* - s.tevelde@erasmusmc.nl; Elisabeth FC van Rossum - e.vanrossum@erasmusmc.nl;

Paul G Voorhoeve - p.voorhoeve@chello.nl; Jos WR Twisk - jwr.twisk@vumc.nl; Henriette A Delemarre van de Waal - H.delemarre@vumc.nl; Coen DA Stehouwer - Csteh@sint.azm.nl; Willem van Mechelen - w.vanmechelen@vumc.nl;

Steven WJ Lamberts - s.w.j.lamberts@erasmusmc.nl; Han CG Kemper - berthankemper@zonnet.nl

* Corresponding author †Equal contributors
\end{abstract}

Published: 0 I June 2005

BMC Endocrine Disorders 2005, 5:5 doi:10.1 186/1472-6823-5-5

This article is available from: http://www.biomedcentral.com/l472-6823/5/5

(c) 2005 te Velde et al; licensee BioMed Central Ltd.

This is an Open Access article distributed under the terms of the Creative Commons Attribution License (http://creativecommons.org/licenses/by/2.0), which permits unrestricted use, distribution, and reproduction in any medium, provided the original work is properly cited.

\begin{abstract}
Objective: To investigate whether IGF-I promoter polymorphism was associated with birth weight and risk factors for cardiovascular disease (CVD) and type 2 diabetes (T2DM), and whether the birth weight - risk factor relationship was the same for each genotype.

Design and participants: 264 subjects (mean age 36 years) had data available on birth weight, IGF-I promoter polymorphism genotype, CVD and T2DM risk factors. Student's t-test and regression analyses were applied to analyse differences in birth weight and differences in the birth weight - risk factors relationship between the genotypes.

Results: Male variant carriers (VCs) of the IGF-I promoter polymorphism had a $0.2 \mathrm{~kg}$ lower birth weight than men with the wild type allele $(p=0.009)$. Of the risk factors for CVD and T2DM, solely LDL concentration was associated with the genotype for the polymorphism. Most birth weight risk factor relationships were stronger in the VC subjects; among others the birth weight - systolic blood pressure relationship: I $\mathrm{kg}$ lower birth weight was related to an $8.0 \mathrm{mmHg}$ higher systolic blood pressure

Conclusion: The polymorphism in the promoter region of the IGF-I gene is related to birth weight in men only, and to LDL concentration only. Furthermore, the genotype for this polymorphism modified the relationships between birth weight and the risk factors, especially for systolic and diastolic blood pressure.
\end{abstract}




\section{Background}

Insulin-like growth factor-1 (IGF-I) is a peptide that is involved in fetal growth and cell differentiation $[1,2]$ In addition, it has been suggested that this peptide plays a role in the regulation of glucose homeostasis and cardiovascular function [3-6] (Lower IGF-I levels are also associated with increased levels of serum low-density lipoprotein (LDL) [7]. IGF-I also plays a role in plaque development [8].

A genetic polymorphism comprising a variable length cytosine-adenine (CA) repeat sequence in the promoter region of the IGF-I gene has been identified, and is thought to influence the transcription rate of IGF-I, which in turn affects serum IGF-I levels [9]. Since IGF-levels are associated with fetal growth and adult risks for cardiovascular disease (CVD) and type 2 diabetes (T2DM), it has been suggested that the polymorphism in the promoter region of the IGF-I gene might be relevant to the fetal origins hypothesis. This hypothesis suggests that an adverse environment during the intra-uterine period negatively affects fetal growth (often estimated by birth weight), and results in adaptations that permanently change the structure and functions of the body, which leads to an increased risk for disease, such as CVD and T2DM, at adult age [10]. An alternative hypothesis is that impaired fetal growth and increased risk for CVD and T2DM share a common genetic factor $[11,12]$ A study performed in Rotterdam in the Netherlands has recently shown that the absence of the wild type allele (192 base pair (bp)) in the promoter region IGF-I gene was related to lower birth weight [13]. In addition, the intra-uterine environment may interact with genetic polymorphisms [14]. This has already been found in other studies, two of which concerned on birth weight and genetic factors in insulin metabolism [15-17] These data raise the issue of whether or not birth weight also interacts with the IGF-I gene.

In the Amsterdam Growth and Health Longitudinal Study (AGAHLS), data on birth weight, and risk factors for CVD and T2DM have been collected. The IGF-I gene has now been analysed for the 192 bp polymorphism [9,13], in order to address the following four research questions: 1) Is the IGF-I promoter polymorphism genotype associated with birth weight? 2) Is IGF-I promoter polymorphism genotype associated with risk factors for CVD and T2DM? 3) Is birth weight associated with risk factors for CVD and T2DM and finally 4) Do intra-uterine environment and the IGF-I promoter polymorphism genotype interact? Or, in other words, is the association between birth weight and risk factors for CVD and T2DM different for each genotype of this polymorphism?

\section{Methods \\ Participants}

The Dutch population described in this study are all participants of the AGAHLS. The AGAHLS is an observational study with repeated measurements, which started in 1976 to monitor boys and girls with a mean age of 13 years [18]. During the most recent measurement in which 433 subjects participated, subjects had than reached a mean age of 36 years, information was obtained concerning birth weight, IGF-I promoter polymorphism genotype, glycated hemoglobin $\left(\mathrm{HbA}_{1 \mathrm{c}}\right)$, carotid intima-media thickness (IMT), blood pressure, anthropometry and serum low density lipoprotein (LDL) cholesterol levels. Threehundred-ninety-one subjects completed the birth-weight questionnaire of whom 380 had written information or information from parents. For the purpose of the present study, subjects who were born pre-term (before 37 weeks of gestation, 27 subjects), were one of a twin (11 subjects) or were of non-Caucasian ethnicity (9 subjects) were excluded. Another 69 subjects were not taken into account for the analyses because of errors or missing values in the genotyping or risk factor measurements. Finally, for 264 subjects (152 women) there were complete data sets on the IGF-I promoter polymorphism genotype, birth weight, and adult risk factors for CVD and T2DM. Subjects included for the analyses were smaller $(1.76 \mathrm{~m}$ vs. $1.77 \mathrm{~m}$, $\mathrm{p}=0.030)$ and had less fat-free mass $(56.5 \mathrm{~kg}$ vs. $57.9 \mathrm{~kg}$, $\mathrm{p}=0.056)$ compared to subjects not included for these analyses, but with data on the outcomes available $(\mathrm{N}=$ 109). On all other outcome variables the groups did not differ. (Some outcome measures had missing values, which were due to error in the specific measurement.) All subjects were apparently healthy at the time of the measurements, and none had been diagnosed with T2DM. All subjects gave written informed consent and the Medical Ethical Committee of the VU University Medical Center approved the protocol.

\section{Birth weight}

Data on birth weight were obtained by means of a questionnaire. The questions concerned birth weight, gestational age, being one of a twin, and ethnicity, and subjects were also asked about the source of the information. Only those who had received the information from their parents or had it in written documents were included, as this has been shown to be a valid method $[19,20]$ Subjects born preterm (gestational age $<37$ weeks) were excluded, this may have independent effects on adult health or influence the relationship between birth weight and adult health [21-23]. Twins were excluded because they have different fetal growth patterns, which might cause error when analysing the relationship between birth weight and adult health outcomes. Subjects who retrieved the birth weight information from their parents' memory $(\mathrm{n}=112)$ had slightly higher mean birth weights $(3.54 \pm 0.53 \mathrm{~kg})$ 
compared with the subjects who retrieved the requested information from written documents $(\mathrm{n}=152 ; 3.44 \pm$ $0.48 \mathrm{~kg}$ ), but this difference was not significant ( $\mathrm{p}=0.10)$. Furthermore, they did not differ significantly on any of the outcome measures.

\section{Polymorphism in the promoter region of the IGF-I gene} IGF-I promoter polymorphism genotypes were determined as described earlier [9]. In brief, DNA was isolated using standard methods. PCR was performed in a final volume of $10 \mu \mathrm{L}$ containing $10 \mathrm{ng}$ DNA, 10* Gold (Au) buffer (Perkins and Elmer), $200 \mathrm{M}$ dNTP, $30 \mathrm{pmol}$ of each primer, $3 \mathrm{mM} \mathrm{MgCl2}$, 0.5 U Ampli Tag Gold polymerase (Perkins and Elmer). The PCR program concisted of 30 cycli of $30 \mathrm{sec} 95^{\circ} \mathrm{C}, 30 \mathrm{sec} 55^{\circ} \mathrm{C}$ and $30 \mathrm{sec} 72^{\circ} \mathrm{C}$ and additionally $5 \mathrm{~min}$ of denaturation at $95^{\circ} \mathrm{C}$ before the first cycle and an extension of $10 \mathrm{~min}$. at $72^{\circ} \mathrm{C}$ after the last cycle. Forward primers were labelled with FAM (Weber \& May 1989) to determine the size of the PCR products by fragment analysis (ABI-Prism genetic analyser with Genescan 2.1 software). The Genescan 350/500 Tamra was used as internal size standard within the fragment analysis.

Rietveld et al[24] recently demonstrated that subjects who were homozygous for the 192 bp or the 194 bp allele had comparable IGF-I blood levels, while individuals who were homozygous for either alleles shorter than 192 bp or longer than 194 bp had significantly lower serum IGF-I levels. Therefore, we decided to regard all subjects who were homozygous for $192 \mathrm{bp}$ or $194 \mathrm{bp}$, or were carrier of a 192 bp allele and a 194 bp allele as wild types (WTs). Consequently, all subjects who were carrier of a variant allele, which is either shorter than 192 bp or longer than $194 \mathrm{bp}$, were grouped as variant carriers (VCs).

\section{Risk factors for CVD and T2DM}

The following risk factors for CVD and T2DM were measured: body mass index (BMI), waist circumference, waistto-hip ratio (WHR), total fat mass (FM), total fat-free mass (FFM), carotid intima-media thickness (IMT), systolic and diastolic blood pressure (SBP, DBP), resting heart rate, LDL cholesterol levels and $\mathrm{HbA}_{1 \mathrm{c}}$ as an estimate of glucose metabolism (unfortunately no glucose measures were available). BMI was calculated as body weight (kg) divided by body height $\left(\mathrm{m}^{2}\right)$. Standing height was measured with a stadiometer to the nearest $0.001 \mathrm{~m}$. Body weight $(\mathrm{kg})$ was measured to the nearest $0.1 \mathrm{~kg}$ using a spring balance scale (Van Vucht, Amsterdam, The Netherlands), with subjects dressed only in underwear. Waist (at the level of the umbilicus) and hip circumference were measured with a flexible steel tape to the nearest $0.1 \mathrm{~cm}$. WHR was calculated as the ratio between waist circumference and hip circumference. Fat mass (FM) was estimated from four skinfolds (biceps, triceps, subscapular and supra iliacal) with the Durnin and Womersley equation [25]. The four skinfolds were measured according to standard procedures [26]. FFM was calculated by subtracting FM from body weight.

IMT of the right common carotid artery was obtained by an ultrasound scanner equipped with a $7.5 \mathrm{MHz}$ linear array probe (Pie Medical, Maastricht, The Netherlands), as described elsewhere in more detail [27-29] SBP and DBP were assessed in the left arm at 5-minute intervals with an oscillometric device (Colin Press-Mate, model BP 8800, Komaki-City, Japan) during the entire period of ultrasound imaging when the subjects were lying in a supine position. The mean value over this entire period was calculated. Resting heart rate was measured with the same device as used for the blood pressure measurement. The mean value over this measurement period was calculated and used in the analyses.

Serum LDL and $\mathrm{HbA}_{1 \mathrm{c}}(\%)$ were measured from blood samples $(10 \mathrm{ml})$ taken from the antecubital vein between 8.30 and 12.30 a.m. with subjects in a non-fasting state. Standard methods were used to analyse the LDL concentration and external quality control took place with target samples from a World Health Organisation reference laboratory (Lipid Standardization Laboratory, Atlanta, USA). $\mathrm{HbA}_{1 \mathrm{c}}$ was determined by non-exchange high performance liquid chromatography with a modular Diabetes Monitoring System (Bio-Rad, Veenendaal, the Netherlands).

\section{Data-analyses}

A t-test was used to analyse differences in birth weight between the IGF-I promoter polymorphism genotypes. Multiple linear regression analyses were applied to study the associations between birth weight and the risk factors for CVD and T2DM. The results of the regression analyses were presented as regression coefficients $(\beta)$ and the corresponding $95 \%$ confidence intervals (CI) for two different models. The first model was a crude analysis, only adjusted for gender (and for SBP and DBP in case of IMT). The second was further adjusted for adult body weight.

To investigate whether the relationship between birth weight and the risk factors for CVD and T2DM were modified by the IGF-I promoter polymorphism, multiple linear regression was performed between birth weight and all risk factors (all as continuous variables) for the two genotypes separately.

All analyses were performed with the Statistical Package of Social Science (SPSS, Chicago, USA) version 10.1. The statistical significance was set at $\mathrm{p}$-value $\leq 0.05$. 
Table I: Allelic and genotype frequencies for the bp repeat polymorphism at the promoter region of the IGF-I gene

\begin{tabular}{|c|c|c|c|c|}
\hline Allele (bp length) & Frequency N (\%) & Genotype & & Frequency N (\%) \\
\hline 176 & $3(0.5)$ & WT & $192 / 192$ & $105(39.8)$ \\
\hline 188 & $10(1.9)$ & & $192 / 194$ & $78(29.5)$ \\
\hline 190 & $23(4.4)$ & & $194 / 194$ & $6(2.3)$ \\
\hline 192 & $341(64.6)$ & & total & 189 (7I.6) \\
\hline 194 & $108(20.5)$ & VC & $192 / x$ & $53(20.0)$ \\
\hline 196 & $38(7.2)$ & & $194 / x$ & $18(6.8)$ \\
\hline \multirow[t]{2}{*}{198} & $5(1.0)$ & & $x / x$ & $4(1.5)$ \\
\hline & & & total & $75(28.4)$ \\
\hline
\end{tabular}

X, alleles with bp lengths other than 192 or 194; WT, Wild Type; VC, Variant Carrier

Table 2: Characteristics of the adult population of the Amsterdam Growth and Health Longitudinal Study

\begin{tabular}{|c|c|c|c|c|}
\hline & \multicolumn{2}{|c|}{ Men } & \multicolumn{2}{|c|}{ Women } \\
\hline & WT & VC & WT & VC \\
\hline & Mean \pm SD & Mean \pm SD & Mean \pm SD & Mean \pm SD \\
\hline Birth weight (kg) & $3.64 \pm 0.47$ & $3.40 \pm 0.39$ & $3.44 \pm 0.53$ & $3.41 \pm 0.52$ \\
\hline Height (m) & $1.84 \pm 0.08$ & $1.83 \pm 0.07$ & $1.71 \pm 0.06$ & $1.72 \pm 0.06$ \\
\hline Weight $(\mathrm{kg})$ & $84.1 \pm 10.8$ & $85.2 \pm 10.8$ & $67.5 \pm 9.3$ & $69.2 \pm 11.8$ \\
\hline Body mass index (kg/m2) & $23.5 \pm 2.6$ & $24.5 \pm 2.4$ & $22.4 \pm 2.9$ & $22.8 \pm 3.8$ \\
\hline Fat-mass (kg) & $13.7 \pm 5.0$ & $15.3 \pm 5.6$ & $17.7 \pm 5.3$ & $18.4 \pm 6.4$ \\
\hline Fat-free mass $(\mathrm{kg})$ & $66.1 \pm 6.6$ & $66.3 \pm 5.7$ & $47.3 \pm 4.5$ & $48.7 \pm 5.9$ \\
\hline Waist circumference $(\mathrm{cm})$ & $85.3 \pm 7.5$ & $85.9 \pm 8.8$ & $73.3 \pm 8.9$ & $73.4 \pm 8.0$ \\
\hline Waist-to-hip ratio & $0.95 \pm 0.04$ & $0.96 \pm 0.05$ & $0.83 \pm 0.08$ & $0.82 \pm 0.08$ \\
\hline Systolic blood pressure $(\mathrm{mmHg})$ & $121.0 \pm 8.9$ & $122.7 \pm 14.4$ & $110.7 \pm 10.6$ & $111.8 \pm 12.0$ \\
\hline Diastolic blood pressure $(\mathrm{mmHg})$ & $66.4 \pm 6.4$ & $67.2 \pm 8.6$ & $63.1 \pm 7.2$ & $61.6 \pm 6.9$ \\
\hline LDL concentration $(\mathrm{mmol} / \mathrm{l})$ & $3.22 \pm 0.80$ & $3.52 \pm 0.87$ & $2.80 \pm 0.81$ & $2.97 \pm 0.70$ \\
\hline Carotid intima-media thickness $(\mathrm{mm})$ & $0.628 \pm 0.099$ & $0.636 \pm 0.095$ & $0.616 \pm 0.086$ & $0.631 \pm 0.101$ \\
\hline Resting heart rate $(\mathrm{b} / \mathrm{min})$ & $73 \pm 12$ & $69 \pm 11$ & $72 \pm 12$ & $70 \pm 12$ \\
\hline Glycated hemoglobin (\%) & $5.3 \pm 0.5$ & $5.3 \pm 0.3$ & $5.3 \pm 0.4$ & $5.3 \pm 0.3$ \\
\hline
\end{tabular}

Data is presented as means \pm standard deviations (SD),

†WT, Wild type; VC, Variant carrier LDL - low lipoprotein

\section{Results}

Table 1 gives allele and genotype frequencies in this cohort. As can be seen, of all 264 subjects, 189 (111 women) were WTs for the IGF-I promoter polymorphism. The remaining 75 subjects (41 women), 4 were homozygous for alleles with variant CA repeats and 71 were heterozygous for variant alleles. The distribution of genotypes was in Hardy-Weinberg equilibrium $(\mathrm{p}=0.17)$.

Population characteristics on all measured variables are presented in Table 2, stratified according to gender and genotype. In men, the mean birth weight was $0.2 \mathrm{~kg}$ lower in the VC group than in the WT group ( $\mathrm{p}=0.009)$. In women, no significant differences in birth weights between the genotypes were observed $(p=0.755)$.
Subjects in the VC group had significantly higher LDL concentrations $(p=0.039)$. No other significant differences between the genotypes were observed.

Table 3 presents the results of the linear regression analyses for the relationship between birth weight and risk factors for CVD and T2DM. It was found that $1 \mathrm{~kg}$ higher birth weight was associated with $2.55 \mathrm{~kg}$ more FFM. However, this association decreased and lost significance after adjustment for adult body weight. In addition, birth weight was found to be associated with SBP in such a way that $1 \mathrm{~kg}$ lower birth weight was related to a $3.05 \mathrm{mmHg}$ higher SBP. No other significant associations were observed between birth weight and risk factors for CVD and T2DM. 
Table 3: Results of the linear regression analyses for the relationship between birth weight and adult risk factors for CVD and DM-2

\begin{tabular}{|c|c|c|c|c|}
\hline & Crudet & & Adjusted & \\
\hline Outcome & $\beta$ & $95 \% \mathrm{Cl}$ & $\beta$ & $95 \% \mathrm{Cl}$ \\
\hline Body mass index $\left(\mathrm{kg} / \mathrm{m}^{2}\right)$ & 0.445 & {$[-0.264 ; 1.154]$} & & \\
\hline Fat-mass $(\mathrm{kg})$ & 0.962 & {$[-0.36 \mathrm{I} ; 2.285]$} & -0.663 & {$[-1.605 ; 0.208]$} \\
\hline Fat-free mass $(\mathrm{kg})$ & $2.553^{* * * *}$ & {$[1.224 ; 3.882]$} & 0.714 & {$[-0.085 ; 1.513]$} \\
\hline Waist circumference $(\mathrm{cm})$ & 1.760 & {$[-0.372 ; 3.892]$} & -1.013 & {$[-2.253 ; 0.227]$} \\
\hline Waist-to-hip ratio & 0.012 & {$[-0.005 ; 0.028]$} & 0.006 & {$[-0.011 ; 0.022]$} \\
\hline Systolic blood pressure $(\mathrm{mmHg})$ & -1.387 & {$[-4.082 ; 1.309]$} & $-3.050 *$ & {$[-5.626 ;-0.475]$} \\
\hline Diastolic blood pressure $(\mathrm{mmHg})$ & -0.692 & {$[-2.445 ; 1.07 I]$} & -1.608 & {$[-3.329 ; 0.113]$} \\
\hline Resting heart rate $(\mathrm{b} / \mathrm{min})$ & 1.941 & {$[-0.932 ; 4.815]$} & $1.86 \mid$ & {$[-1.081 ; 4.803]$} \\
\hline Low density lipoprotein (mmol/l) & -0.079 & {$[-0.277 ; 0.118]$} & -0.154 & {$[-0.351 ; 0.044]$} \\
\hline Carotid intima-media thickness $(\mathrm{mm}) \|$ & 0.011 & {$[-0.012 ; 0.034]$} & 0.011 & {$[-0.012 ; 0.035]$} \\
\hline Glycated hemoglobin (\%) & -0.013 & {$[-0.109 ; 0.082]$} & -0.025 & {$[-0.123 ; 0.072]$} \\
\hline
\end{tabular}

Data is presented as regression coefficients and corresponding $95 \%$ confidence intervals $(\mathrm{Cl})$

CVD - cardiovascular disease; DM-2 - type 2 diabetes mellitus

$\dagger$ Crude, only adjusted for gender; $\neq$, Adjusted, further adjusted for adult body weight

$* p<0.05 * * * p<0.001$

|| also adjusted for systolic and diastolic blood pressure

Table 4: Analyses stratified according to genotype for the relationship between birth weight and risk factors for CVD and DM-2

\begin{tabular}{|c|c|c|c|c|}
\hline & Wild type & & Variant carrier & \\
\hline Risk factor & $\beta$ & $95 \% \mathrm{Cl}$ & $\beta$ & $95 \% \mathrm{Cl}$ \\
\hline BMI $\left(\mathrm{kg} / \mathrm{m}^{2}\right)$ & 0.475 & {$[-0.312 ; 1.262]$} & 0.777 & {$[-0.835 ; 2.338]$} \\
\hline Fat mass $(\mathrm{kg})$ & -0.217 & {$[-1.337 ; 0.904]$} & $-1.929 *$ & {$[-3.742 ;-0.116]$} \\
\hline Fat free mass $(\mathrm{kg})$ & 0.780 & {$[-0.212 ; 1.722]$} & 0.473 & {$[-0.897 ; 1.844]$} \\
\hline Waist circumference $(\mathrm{cm})$ & -1.380 & {$[-2.822 ; 0.061]$} & 0.040 & {$[-2.588 ; 2.668]$} \\
\hline Waist-hip ratio & 0.002 & {$[-0.016 ; 0.021]$} & 0.021 & {$[-0.015 ; 0.057]$} \\
\hline Systolic blood pressure $(\mathrm{mmHg})$ & -1.497 & {$[-4.265 ; 1.272]$} & $-8.038^{*}$ & {$[0.014 ;-14.391]$} \\
\hline Diastolic blood pressure $(\mathrm{mmHg})$ & -0.599 & {$[-2.553 ; 1.355]$} & $-5.073 * *$ & {$[-8.845 ;-1.301]$} \\
\hline LDL cholesterol (mmol/l) & -0.138 & {$[-0.369 ; 0.093]$} & -0.076 & {$[-0.491 ; 0.339]$} \\
\hline Resting heart rate $(\mathrm{b} / \mathrm{min})$ & 2.540 & {$[-0.865 ; 5.946]$} & -1.995 & {$[-8.277 ; 4.286]$} \\
\hline Carotid intima-media thickness $(\mathrm{mm}) \ddagger$ & 0.010 & {$[-0.017 ; 0.036]$} & 0.020 & {$[-0.035 ; 0.075]$} \\
\hline Glycated hemoglobin (\%) & -0.019 & {$[-0.138 ; 0.101]$} & -0.025 & {$[-0.207 ; 0.157]$} \\
\hline
\end{tabular}

Data is presented as regression coefficients $(\beta)$ and their corresponding $95 \%$ confidence intervals $(\mathrm{Cl})$

CVD - cardiovascular disease; DM-2 - type 2 diabetes mellitus

Models were adjusted for gender and adult body weight $* p<0.05 * * p<0.01$

$\ddagger$ also adjusted for systolic and diastolic blood pressure

Table 4 shows the results of the linear regression analyses between birth weight and the risk factors for CVD and T2DM, stratified according to IGF-I promoter polymorphism genotypes. In most of the associations studied, the regression coefficient for birth weight was highest in the VC group, indicating a stronger effect of birth weight on the outcome variable. This difference was most marked in the association with SBP, in which a $1 \mathrm{~kg}$ lower birth weight was related to an $8.0 \mathrm{mmHg}$ increase in adult SBP in the VC group, compared to a $1.4 \mathrm{mmHg}$ increase in the WT group. Although, the difference between the VC group and WT group was not statistically significant $(\mathrm{p}=0.08)$ for these kind of 'interactions' normally a higher significance level is used. In addition, the relationships between birth weight and DBP and FM were significant in the VC group and not in the WT group ( $\mathrm{p}=0.06$ for the difference between VCs and WTs for DBP). The differences between VCs and WTs regarding all other relationships showed pvalues $>0.10$.

For the associations between birth weight and adult FFM, waist circumference, LDL and resting heart rate, the regres- 
sion coefficients were highest in the WT group, although none of these associations were statistically significant.

\section{Discussion}

In this study, the associations between a polymorphism in promoter region of the IGF-I gene, birth weight, (as a measure of intra-uterine growth), and risk factors for CVD and T2DM were investigated, in order to obtain more insight into the genetic aspects of the fetal origins hypothesis $[1,5,6,30,31]$ (The results of the present study demonstrate that men who were carriers of one or two variant allele(s) of the IGF-I gene had significantly lower birth weights. However, this trend was not observed in women. It is not clear, why this association was absent in women, as no other study has reported gender differences in the association between IGF-I genotype and birth weight $[13,32,33]$. Therefore, the gender difference observed in this study might be a result of chance

So far, results on the association between IGF-I genotype and birth weight have been conflicting. Vaessen et al. reported that absence of the wild type allele (192 bp) resulted in a lower birth weight, but subjects who were heterozygous for the wild type allele did not differ in birth weight from the homozygous subjects [13]. Nevertheless, Vos et al. [33], Frayling et al. [32] and Day et al [34] could not confirm these findings. These conflicting results could be due to differences in the population backgrounds, but also to the way in which subjects were classified per genotype. In the present study, an alternative method was used, in which the allele with 194 bp was also considered as a wild type allele, based on the observations made by Rietveld et al[24]. Subjects previously categorised as VC were now categorised as WT (e.g. subjects with genotype 192 bp/194 bp, or 194 bp/194 bp). Therefore, the VC group in other studies was actually heterogeneous, which may explain discrepant observations. To investigate this possible explanation, we investigated the characteristics of the subjects who would have been categorised as VC according to the traditional classification, and were now categorised as WT (84 subjects). The men in this group had a mean birth weight of $3.63 \mathrm{~kg}( \pm 0.51 \mathrm{~kg})$, which is comparable with the men who were categorised as WT in both classification methods $(3.64 \pm 0.43 \mathrm{~kg})$. The women in this group had a mean birth weight of $3.44 \mathrm{~kg}( \pm 0.53$ $\mathrm{kg}$ ), which is exactly the same as the women classified as WT in both methods. Besides this, the three groups were also different with regard to the interaction between birth weight and SBP and DBP in a way that the relationship between birth weight and adult SBP and DBP was strongest and significant in the 'constant' VCs $(\beta=-8.0$ for SBP and $\beta=-5.1$ for $\mathrm{DBP}$ ), and weak and not significant in the two other groups. These results suggest that the alternative method used in the present paper discriminates better between the genotypes with regard to the observed health outcomes.

The results concerning risk factors for CVD and T2DM showed an increased risk in the VC group solely for LDL concentrations, all other risk factors did not differ between WT and VC groups. That only one risk factor was significantly different between the groups might be real or a result of chance, since we tested several associations. Moreover, the relationship between IGF-I genotype and LDL concentrations disappeared after adjustment for BMI and there were no differences in HDL concentrations ( $\mathrm{p}=$ 0.255 , data not shown). Several studies have shown that lower IGF-I bio-activity is related to higher incidence of atherosclerotic cardiovascular disease, higher carotid IMT values, lower levels of HDL cholesterol, and impaired glucose tolerance $[5-7,35]$. (However, other studies have failed to show these associations [36-38] Until now, observations have thus been inconsistent, which may be due to other factors that affect cardiovascular health, insulin metabolism and serum IGF-I levels, such as nutrition and endocrine factors. One should, however, realise that the subjects of the present study were still rather young (i.e. 36 years), and that a longer exposure to lower IGF-I bioactivity might be necessary to induce unfavourable levels of risk factors for CVD and/or T2DM.

Another aim of the present study was to investigate whether birth weight was associated with risk factors for CVD and T2DM. This was found to be the case for FFM, however this association decreased after adjustment for body weight. When studying this association within tertiles of BMI, it was found that only in the $2^{\text {nd }}$ tertile the relationship between birth weight and FFM was significant (data not shown). Another significant association was found between birth weight and for SBP, which is in line with others and previously found in the AGAHLS[39,40]. No other significant associations were found, although the associations between birth weight and adult LDL, FM and waist circumference were in the expected (negative) directions [41-46] No associations were found between birth weight and resting heart rate or carotid IMT. This latter finding is in contrast with what has been reported by Leeson et al. [47]. However, their study focussed on an older population.

Birth weight is considered to be mainly dependent on the intra-uterine environment, such as the availability of nutrients and oxygen [30]. In the present population, the IGF-I genotype could only explain $6 \%$ of the variance in birth weight in men, and only $1 \%$ of the variance in birth weight in women. The magnitude of the relationship between birth weight and risk factors for CVD and T2DM, however, seems to be dependent on genes (i.e. IGF-I promoter polymorphism) (Table 4 ). This modification was 
strongest in the association between birth weight and blood pressure. In the VC group, a $1 \mathrm{~kg}$ lower birth weight was found to be related to an $8 \mathrm{mmHg}$ increase in SBP, which is much more than has been reported in the literature (2 to $3 \mathrm{~mm} \mathrm{Hg}$ ) [39]. The relationship between birth weight and DBP was also stronger than was expected (as 1 $\mathrm{kg}$ lower birth weight was related to a $5 \mathrm{mmHg}$ increase in DBP). No other study has reported on interactions between genes and birth weight in the relationship with adult blood pressure, although IJzerman et al, in twins studies, have shown that the association between birth weight and blood pressure depends on genetic factors $[48,49]$ Interactions between birth weight and other genes have been reported before, which might suggest that some genotypes are more prone to adverse circumstances during fetal growth, under the assumption that birth weight is mainly dependent on the intra-uterine environment [15-17] On the other hand, the observed interactions between birth weight and IGF-I promoter polymorphism genotype could be a result of a gene-gene interaction, since birth weight is also determined by genes (other than the IGF-I gene).

This study was conducted in 264 subjects only, which is considered few in studies on genetic associations. This might be a reason that we did not find significant associations between genotype and the risk factors. Subjects born pre term were excluded, since gestational age may be another factor associated with risk factors for CVD and T2DM, but with another underlying mechanism [21]. We reanalysed the data including subjects born pre term but fulfilling the other inclusion criteria $(N=22)$, which showed some different $\beta$ 's (birth weight was now significantly associated with FM, waist circumference (unadjusted model) and with DBP pressure (adjusted model)). However, the interaction between birth weight and IGF-I genotype was the same, with strong associations between birth weight and SBP and DBP in the VC $(\beta=-8.40$ and $\beta$ $=-5.67$, respectively). Furthermore, despite the fact that the AGAHLS is a longitudinal study, no data was available on infant growth, nor reliable data on birth length was available. If so, it was possible to study effects of IGF-I genotype on infant growth or interactions with infant growth.

\section{Conclusion}

From this study, it is concluded that IGF-I promoter polymorphism genotype is related to birth weight in men only, that this genotype is not associated with risk factors for CVD and T2DM, and, most interestingly, that the IGFI promoter polymorphism genotype modifies the relationship between birth weight and risk factors for CVD and T2DM, especially for SBP and DBP.

\section{List of abbreviations}

$\beta$ - regression coefficient
$95 \% \mathrm{CI}$ - 95\% confidence interval

AGAHLS - Amsterdam Growth and Health Longitudinal Study

BMI - body mass index

bp - base pair

$\mathrm{CA}$ - cytosine adenine

CVD - cardiovascular diseases

DBP - diastolic blood pressure

T2DM - type 2 diabetes

FFM - fat-free mass

FM - fat-mass

$\mathrm{HbA}_{1 \mathrm{c}}$ - glycated hemoglobin

IGF-1 - insulin like growth factor 1

IMT - intima-media thickness

LDL - low density lipoprotein

SBP - systolic blood pressure

VC - variant carrier

WHR - waist-to-hip ratio

WT - wild type

\section{Competing interests}

The author(s) declare that they have no competing interests.

\section{Authors' contributions}

The first three authors (StV, EvR and PV) equally contributed to the paper. They were involved in the statistical analysis, interpretations of the data, laboratory work to determine the IGF-I polymorphism and writing of the paper.

JT, HD, CS, WvM, SL and HK were supervisors and involved in developing the design, assist in statistical analysis and interpretation of the results. They all have been involved in drafting the article or revising it critically for important intellectual content. All authors read and approved the final manuscript. 


\section{Acknowledgements}

The AGAHLS is supported by multiple grants from the Dutch Prevention Fund (ZON), Dutch Heart Foundation (NHS), Dutch Ministry of Education an Science, Dutch Ministry of Well Being, Public Health and Sports (VWS), the Dairy Foundation on Nutrition and Health (ZVG), Dutch Olympic Committee / Dutch Sports Foundation (NOC/NSF), Scientific Board Smoking and Health, and Heineken Inc. We would like to thank all the men and women who participated in the AGAHLS

\section{References}

I. Lo HC, Tsao LY, Hsu WY, Chen HN, Yu WK, Chi CY: Relation of cord serum levels of growth hormone, insulin-like growth factors, insulin-like growth factor binding proteins, leptin, and interleukin-6 with birth weight, birth length, and head circumference in term and preterm neonates. Nutrition 2002, 18:604-608.

2. Liu JL, LeRoith D: Insulin-like growth factor $\mathbf{I}$ is essential for postnatal growth in response to growth hormone. Endocrinology 1999, I 40:5178-5184.

3. Holt RI, Simpson HL, Sonksen PH: The role of the growth hormone-insulin-like growth factor axis in glucose homeostasis. Diabet Med 2003, 20:3-15.

4. Le Roith D, Bondy C, Yakar S, Liu JL, Butler A: The somatomedin hypothesis: 200I. Endocr Rev 200I, 22:53-74.

5. Sandhu MS, Heald AH, Gibson JM, Cruickshank JK, Dunger DB, Wareham NJ: Circulating concentrations of insulin-like growth factor-I and development of glucose intolerance: a prospective observational study. Lancet 2002, 359:1740-1745.

6. Janssen JA, Stolk RP, Pols HA, Grobbee DE, de Jong FH, Lamberts SW: Serum free IGF-I, total IGF-I, IGFBP-I and IGFBP-3 levels in an elderly population: relation to age and sex steroid levels. Clin Endocrinol (Oxf) 1998, 48:47I-478.

7. Ceda GP, Dall'Aglio E, Magnacavallo A, Vargas N, Fontana V, Maggio M, Valenti G, Lee PD, Hintz RL, Hoffman AR: The insulin-like growth factor axis and plasma lipid levels in the elderly. J Clin Endocrinol Metab 1998, 83:499-502.

8. Bayes-Genis A, Conover CA, Schwartz RS: The insulin-like growth factor axis: $A$ review of atherosclerosis and restenosis. Circ Res 2000, 86: 125-130.

9. Vaessen N, Heutink P, Janssen JA, Witteman JC, Testers L, Hofman A, Lamberts SW, Oostra BA, Pols HA, van Duijn CM: A polymorphism in the gene for IGF-I: functional properties and risk for type 2 diabetes and myocardial infarction. Diabetes 200I, 50:637-642.

10. O'brien PMS, Wheeler T, Barker DJ: Fetal programming: influences ondevelopment and disease in later life. , RCOG Press; 1998.

II. Young LE: Imprinting of genes and the Barker hypothesis. Twin Res 200I, 4:307-317.

12. Hattersley AT, Tooke JE: The fetal insulin hypothesis: an alternative explanation of the association of low birthweight with diabetes and vascular disease. Lancet 1999, 353:1789-1792.

13. Vaessen N, Janssen JA, Heutink P, Hofman A, Lamberts SW, Oostra $B A$, Pols HA, van Duijn CM: Association between genetic variation in the gene for insulin-like growth factor-I and low birthweight. Lancet 2002, 359:1036-1037.

14. Ottman R: An epidemiologic approach to gene-environment interaction. Genet Epidemiol 1990, 7: 177-185.

15. Dennison EM, Arden NK, Keen RW, Syddall H, Day IN, Spector TD, Cooper C: Birthweight, vitamin $D$ receptor genotype and the programming of osteoporosis. Paediatr Perinat Epidemiol 200I, 15:211-219.

16. Eriksson JG, Lindi V, Uusitupa M, Forsen TJ, Laakso M, Osmond C, Barker DJ: The effects of the Prol 2 Ala polymorphism of the peroxisome proliferator-activated receptor-gamma2 gene on insulin sensitivity and insulin metabolism interact with size at birth. Diabetes 2002, 5 I:232 I-2324.

17. Jaquet D, Tregouet DA, Godefroy T, Nicaud V, Chevenne D, Tiret L, Czernichow P, Levy-Marchal C: Combined effects of genetic and environmental factors on insulin resistance associated with reduced fetal growth. Diabetes 2002, 5 I:3473-3478.

18. Kemper HC, van Mechelen W, Post GB, Snel J, Twisk JW, van Lenthe Fj, Welten DC: The Amsterdam Growth and Health Longitu- dinal Study. The past (1976-1996) and future (1997-?). Int J Sports Med 1997, 18 Suppl 3:SI 40-50.

19. Troy LM, Michels KB, Hunter DJ, Spiegelman D, Manson JE, Colditz GA, Stampfer MJ, Willett WC: Self-reported birthweight and history of having been breastfed among younger women: an assessment of validity. Int J Epidemiol 1996, 25: I 22-127.

20. O'Sullivan JJ, Pearce MS, Parker L: Parental recall of birth weight: how accurate is it? Arch Dis Child 2000, 82:202-203.

21. Oren A, Vos LE, Bos WJ, Safar ME, Uiterwaal CS, Gorissen WH, Grobbee $\mathrm{DE}$, Bots ML: Gestational age and birth weight in relation to aortic stiffness in healthy young adults: two separate mechanisms? Am J Hypertens 2003, 16:76-79.

22. Leon DA, Johansson M, Rasmussen F: Gestational age and growth rate of fetal mass are inversely associated with systolic blood pressure in young adults: an epidemiologic study of 165,136 Swedish men aged 18 years. Am J Epidemiol 2000, 152:597-604.

23. Siewert-Delle A, Ljungman S: The impact of birth weight and gestational age on blood pressure in adult life: a populationbased study of 49-year-old men. Am J Hypertens 1998, I I:946-953.

24. Rietveld I, Janssen JA, van Rossum EF, Houwing-Duistermaat JJ, Rivadeneira F, Hofman A, Pols HA, van Duijn CM, Lamberts SW: A polymorphic CA repeat in the IGF-I gene is associated with gender-specific differences in body height, but has no effect on the secular trend in body height. Clin Endocrinol (Oxf) 2004, 61:195-203.

25. Durnin JV, Womersley J: Body fat assessed from total body density and its estimation from skinfold thickness: measurements on $48 \mathrm{I}$ men and women aged from 16 to 72 years. $\mathrm{Br}$ J Nutr 1974, 32:77-97.

26. Weiner JS, Lourie JA: Human Biology, a guide to field methods. In IBP Handbook Volume no 9. Oxford, Blackwell; 1968.

27. Ferreira I, Twisk JW, Van Mechelen W, Kemper HC, Stehouwer CD: Current and adolescent levels of cardiopulmonary fitness are related to large artery properties at age 36: the Amsterdam Growth and Health Longitudinal Study. Eur J Clin Invest 2002, 32:723-73I.

28. Brands PJ, Hoeks AP, Willigers J, Willekes C, Reneman RS: An integrated system for the non-invasive assessment of vessel wall and hemodynamic properties of large arteries by means of ultrasound. Eur J Ultrasound 1999, 9:257-266.

29. Hoeks AP, Willekes C, Boutouyrie P, Brands PJ, Willigers JM, Reneman RS: Automated detection of local artery wall thickness based on M-line signal processing. Ultrasound Med Biol 1997, 23:1017-1023.

30. Holt RI: Fetal programming of the growth hormone-insulinlike growth factor axis. Trends Endocrinol Metab 2002, I 3:392-397.

31. Giudice LC, de Zegher F, Gargosky SE, Dsupin BA, de las Fuentes L, Crystal RA, Hintz RL, Rosenfeld RG: Insulin-like growth factors and their binding proteins in the term and preterm human fetus and neonate with normal and extremes of intrauterine growth. J Clin Endocrinol Metab 1995, 80: I548- I555.

32. Frayling TM, Hattersley AT, McCarthy A, Holly J, Mitchell SM, Gloyn AL, Owen K, Davies D, Smith GD, Ben-Shlomo Y: A putative functional polymorphism in the IGF-I gene: association studies with type 2 diabetes, adult height, glucose tolerance, and fetal growth in U.K. populations. Diabetes 2002, $51: 2313-2316$.

33. Vos LE: Early determinants of cardiovascular risk in the young: Two Dutch Cohorts. In Julius Centre Utrecht, Utrecht University; 2003.

34. Day INM: Insulin-like growth factor-I genotype and birthweight. The Lancet 2002, 360:945.

35. van den Beld AW, Bots ML, Janssen JA, Pols HA, Lamberts SW, Grobbee DE: Endogenous hormones and carotid atherosclerosis in elderly men. Am J Epidemiol 2003, 157:25-31.

36. Leinonen ES, Salonen JT, Salonen RM, Koistinen RA, Leinonen PJ, Sarna SS, Taskinen MR: Reduced IGFBP-I is associated with thickening of the carotid wall in type 2 diabetes. Diabetes Care 2002, 25: $1807-1812$.

37. Maccario M, Ramunni J, Oleandri SE, Procopio M, Grottoli S, Rossetto R, Savio P, Aimaretti G, Camanni F, Ghigo E: Relationships between IGF-I and age, gender, body mass, fat distribution, metabolic and hormonal variables in obese patients. Int J Obes Relat Metab Disord 1999, 23:612-618.

38. Heald AH, Cruickshank JK, Riste LK, Cade JE, Anderson S, Greenhalgh A, Sampayo J, Taylor W, Fraser W, White A, Gibson JM: Close 
relation of fasting insulin-like growth factor binding proteinI (IGFBP-I) with glucose tolerance and cardiovascular risk in two populations. Diabetologia 200I, 44:333-339.

39. Law CM, Shiell AW: Is blood pressure inversely related to birth weight? The strength of evidence from a systematic review of the literature. J Hypertens 1996, 14:935-94I.

40. te Velde SJ, Ferreira I, Twisk JW, Stehouwer CD, van Mechelen W, Kemper HC: Birthweight and arterial stiffness and blood pressure in adulthood--results from the Amsterdam Growth and Health Longitudinal Study. Int J Epidemiol 2004, 33:154-16I.

41. Ziegler B, Johnsen SP, Thulstrup AM, Engberg M, Lauritzen T, Sorensen HT: Inverse association between birth weight, birth length and serum total cholesterol in adulthood. Scand Cardiovasc J 2000, 34:584-588.

42. Barker DJ, Martyn CN, Osmond C, Hales CN, Fall CH: Growth in utero and serum cholesterol concentrations in adult life. $\mathrm{Bmj}$ 1993, 307:1524-1527.

43. Fall CH, Osmond C, Barker DJ, Clark PM, Hales CN, Stirling Y, Meade TW: Fetal and infant growth and cardiovascular risk factors in women. Bmj 1995, 3 10:428-432.

44. Loos RJ, Beunen G, Fagard R, Derom C, Vlietinck R: Birth weight and body composition in young adult men--a prospective twin study. Int J Obes Relat Metab Disord 200I, 25: I537-I545.

45. Loos RJ, Beunen G, Fagard R, Derom C, Vlietinck R: Birth weight and body composition in young women: a prospective twin study. Am J Clin Nutr 2002, 75:676-682.

46. Ravelli AC, van Der Meulen JH, Osmond C, Barker DJ, Bleker OP: Obesity at the age of $50 \mathrm{y}$ in men and women exposed to famine prenatally. Am J Clin Nutr 1999, 70:81 I-816.

47. Leeson CP, Kattenhorn M, Morley R, Lucas A, Deanfield JE: Impact of low birth weight and cardiovascular risk factors on endothelial function in early adult life. Circulation 200I, 103:1264-1268.

48. IJzerman RG, Stehouwer CD, de Geus EJ, van Weissenbruch MM, Delemarre-van de Waal HA, Boomsma DI: Low birth weight is associated with increased sympathetic activity: dependence on genetic factors. Circulation 2003, 108:566-57I.

49. IJzerman RG, Stehouwer CD, Boomsma DI: Evidence for genetic factors explaining the birth weight-blood pressure relation. Analysis in twins. Hypertension 2000, 36:1008-1012.

\section{Pre-publication history}

The pre-publication history for this paper can be accessed here:

http://www.biomedcentral.com/1472-6823/5/5/prepub
Publish with Bio Med Central and every scientist can read your work free of charge

"BioMed Central will be the most significant development for disseminating the results of biomedical research in our lifetime. "

Sir Paul Nurse, Cancer Research UK

Your research papers will be:

- available free of charge to the entire biomedical community

- peer reviewed and published immediately upon acceptance

- cited in PubMed and archived on PubMed Central

- yours - you keep the copyright 